\title{
Share Structure And Wealth Effects Of Corporate Takeovers
}

Onur Arugaslan, Western Michigan University, USA

Jim DeMello, Western Michigan University, USA

Devrim Yaman, Western Michigan University, USA

\begin{abstract}
In this study we examine the stock price effects of corporate takeovers by dual class firms and unified firms. Our sample consists of 852 firms that were bidders in takeovers between 1993 and 2009. Our univariate and OLS regression results show that both dual class firms and unified firms obtain insignificant returns for various takeover announcement periods. The average and median returns for these two groups are similar to each other. We also identify several factors that the literature suggests should affect the bidder announcement returns in takeovers. Our results indicate that smaller firms in our sample and firms that pay for the acquisition in cash obtain higher abnormal returns when they announce the takeover. In addition, we find that the factors we identify have different influences on the announcement returns of dual class and unified firms. Specifically, unified firms that engage in tender offers and larger firms obtain more positive announcement returns compared to dual class firms whereas unified firms obtain more negative results when the target firm is a public firm.
\end{abstract}

Keywords: Share Structure; Corporate Takeovers; Wealth Effects; Dual Class Stocks

\section{INTRODUCTION}

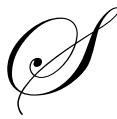

tock price effects of corporate takeovers are a part of the costs of corporate acquisitions. For example, Walker (2000) shows that bidders lose $3.35 \%$ of their market value when they acquire other companies in order to diversify their operations. Chang (1998) finds that firms lose $2.46 \%$ of their market value in stock offers to purchase public firms. Similarly, Draper and Paudyal (2006) show that firms lose $0.4 \%$ of their market value when they bid for listed firms. These studies indicate that the wealth effects of acquisitions can be significant and therefore it is important to study the stock price effects of corporate takeovers and the factors that affect these announcement returns.

In the last decade there has been a lot of attention in academic literature on dual class shares and share unification. Dual class companies are characterized with multiple classes of shares with different voting rights. With dual class shares insiders can achieve controlling positions by providing only a small portion of the equity capital. Although in certain situations dual class shares can benefit shareholders, the deviation from one share - one vote structure can decrease firm value, increase cost of capital, and lead to investment constraints. As a result, some firms choose to unify their shares into a single class. We refer to these firms as "unified firms" in this paper. Through share unification, firms can increase market valuation by reducing profit diversion, increasing liquidity, and improving the availability of the shares to a large group of investors (Pajuste, 2005). Since dual class shares and share unification can lead to significant costs and benefits for corporations and their shareholders it is important to understand the incentives and consequences of unification.

In this study we tie the two separate streams of literature together and study the stock price effects of dual class firms and unified firms in corporate takeovers. To our knowledge, this is the first study to do so. Holmen and Nivorozkin (2005) show that the probability of takeover is a factor in the valuation of dual class shares. By analyzing how dual class and unified stocks behave in a takeover, we can gain insights about the pricing differentials of dual class and unified stocks. 
When we study the characteristics of our sample firms, we find that there are significant differences in size, growth opportunities, and leverage between the dual class firms and unified firms. Several of the characteristics of the acquisition deals of these firms such as the transaction value, type of bid, the purpose of the acquisition, and the acquisition technique used are also different for dual class and unified firms. Therefore, the factors that affect the announcement returns of these firms can be different for these two groups of firms. Hence, we also study the differential impact of the factors that the literature suggests should affect the announcement returns of dual class and unified firms.

Our sample consists of corporate takeovers done by 211 unified firms and 641 dual class firms between 1993 and 2009. Our univariate analysis indicates that, unlike other firms studied in the literature that obtain negative returns, both unified and dual class firms obtain positive but insignificant returns in general. This result persists when we control for other factors that may influence the announcement returns of takeovers in OLS regressions. We also study the influence of the factors that the literature suggests should affect the announcement returns in takeovers. We find that larger firms in our sample obtain lower announcement returns while firms that pay for the acquisition in cash obtain higher returns. In addition, we find that unified firms that engage in tender offers and those that acquire public firms obtain lower returns than dual class firms. However, the announcement returns of larger unified firms are higher compared to similar dual class firms.

Our paper is organized as follows. In the next section, we develop our hypotheses. In section three, we present the characteristics of our data and the results of the empirical tests of our hypotheses. Section four concludes the paper.

\section{HYPOTHESES}

In this section, we identify the hypotheses we test in the paper. We have two sets of hypotheses. In the first set, we develop the hypotheses explaining how stock prices should react when unified and dual class firms announce their acquisition of another firm and whether these reactions should be different for these two groups of firms. In the second set of hypotheses, we identify the variables that the literature suggests should affect the stock prices in takeovers.

\subsection{Announcement Returns of Unified and Dual Class Firms}

Arugaslan (2007) argues that dual class firms are more prone to moral hazard problems since the high voting rights can entrench managers and distort their incentives to maximize firm value. He reports that sample firms are involved in more mergers and acquisitions and boost their investments following dual class stock unifications. These actions are consistent with a reduction in the cost of equity achieved through the unification. Since unified firms can obtain the capital necessary to acquire the target at a lower cost, the acquisition will be a less costly process for these firms. Therefore, the stock price reaction to unified acquirer firms will be more favorable compared to that for dual class firms.

In a similar vein, Bigelli and Mengoli (2004) find that in acquisitions, the non-voting shares obtain negative and significantly lower excess returns than voting shares. This result indicates that there is overpayment for acquisitions made by dual class firms in order to generate greater private benefits for the voting shareholders. To the extent that moral hazard problems are more severe in dual class firms leading to a higher overpayment in acquisitions, unified acquirer firms will obtain higher stock price reaction to the acquisition announcement compared to the reaction for dual class firms.

DeAngelo and DeAngelo (1985) and Fischel (1987) suggest the opposite effect. DeAngelo and DeAngelo (1985) show that managers in dual class firms have a much larger ownership interest in the class with superior voting rights. Thus, these managers contract with the stockholders to limit the competition for their jobs. Since both stockholders and managers voluntarily agree to the higher voting rights for managers, limited competition for management should benefit companies on average. 
Fischel (1987) also argues that dual class structure can benefit firms. First, the market value of firms with dual class shares can be higher when investors value the continuity of management provided by the founding entrepreneur. Second, managers may be more likely to invest their time to learn about the firm when they have more job security through higher voting rights. Third, insider control decreases the need for managers to use their resources to convince bidders that the firm's assets are used efficiently. Fourth, in case of an acquisition, the shareholders of the target firm can get a higher price when there is insider control.

\subsection{Factors Affecting Announcement Returns}

Literature suggests that several issue-specific and firm-specific factors should affect the announcement returns. We discuss our hypotheses related to these variables below:

i) Tender Offer: Copeland and Weston (1992) indicate that the means and motives of a merger may differ in a tender offer and therefore the impact on shareholder value might be different than other mergers. For example, in a tender offer there is usually less information leakage before the formal merger announcements. In addition, in a tender offer there is a greater probability that the shares of the target are undervalued or the bidder perceives an opportunity to improve the management of the target firm. Hence, we expect this variable to have a positive influence on the announcement returns of the firms in our sample.

ii) Bidder Size: Moeller et al. (2004) show that small acquirer firms obtain about two percentage points higher announcement returns compared to the returns of larger firms. They show that their result is robust to different kinds of financing methods, for private and public firms, for various firm and deal characteristics, and this size effect does not change over time. Therefore, we expect larger firms in our sample to have lower announcement returns when they acquire other firms. We measure the size of the bidder with the total assets of the firm.

iii) Method of payment: Travlos (1987) shows that in pure stock exchange acquisitions acquiring firms obtain significant negative returns but they obtain normal returns in cash offers. Travlos shows that the payment effect persists regardless of the type of acquisition. Fuller et al. (2002) also show that bidder returns are insignificant for cash offers and significantly negative for stock offers when they acquire a public firm. Thus, we expect firms that pay for the acquisition in cash, as opposed to other payment methods such as stocks, to have better stock price reactions.

iv) Ownership Structure: Draper and Paudyal (2006) argue that private firm acquisitions are more likely to be motivated by potential synergies and shareholder maximization, and less likely to be influenced by the manager's desire for prestige and for maximizing his or her private benefit compared to the acquisitions of public firms. Acquiring firms may also be underpaying for the target private firms because the market for these firms is illiquid. Consistent with these arguments Draper and Paudyal (2006) find that if the target is private, the bidder announcement returns are higher compared to the returns for public target firms. These arguments suggest that firms that acquire a public company should obtain lower announcement returns.

v) Purpose: Walker (2000) shows that the strategic objective of the executives of merging firms is a significant factor in announcement returns. He shows that firms which expand their operations geographically or increase their market share obtain higher returns than firms with other objectives and these two objectives are the most profitable takeover strategies. Hence, we expect firms with this purpose to obtain better stock price reactions when they announce the acquisition.

vi) Same Industry: Morck et al. (1990) and Maquieira et al. (1995) show that announcement returns for bidders are higher when the acquirer and the target firm operate in a similar line of business. They argue that acquisitions that increase focus provide more synergy gains than acquisitions that result in diversification. Moreover, in focusincreasing acquisitions there is lower chance of overpayment. These arguments suggest that when the bidder and the target are in the same industry, the bidder obtains more favorable stock price reaction. We define the industry of the firm with its one-digit SIC code. 
vii) Tobin's Q: Lang, Stulz, and Walkling $(1989,1991)$ and Servaes $(1991)$ show that the announcement returns of acquirers are lower when the acquirer's Tobin's $Q$ is lower. This is because firms with low Tobin's $\mathrm{Q}$ do not have profitable investment opportunities and therefore are more prone to free cash flow problems. Therefore, we expect Tobin's Q to have a positive influence on the announcement returns of our sample firms. As in Faccio et al. (2006) we measure Tobin's $\mathrm{Q}$ as the market value of the acquirer's equity as of the calendar year-end prior to the announcement date plus the book value of debt and preferred stock from the most recent financial statement prior to the acquisition announcement divided by the sum of the book values of equity, debt, and preferred stock as of the same date.

\section{DATA AND EMPIRICAL ANALYSIS}

In this section, we first present the characteristics of our data followed by the results of the tests of our hypotheses. We perform both univariate and multivariate analyses to test our hypotheses on the differences between the announcement returns of unified and dual class firms. We run multivariate regressions to test the factors that influence the announcement returns of unified and dual class firms.

\subsection{Sample Formation}

In order to determine our unified and dual class samples, we initially identify firms that issued dual class shares between 1925 and 2001. To accomplish this, we first search all of the permanent numbers in the Center for Research in Security Prices (CRSP) that correspond to firms that traded in 1992. This results in $1,567,056$ observations. Next, we obtain the share class data for these firms from 1925 to 1992 . There were 73,142 observations with non-blank share class data. Eliminating tracking stocks (share classes $\mathrm{E}$ and $\mathrm{H}$ ), foreign companies (share codes 12 and 15), American Depository Receipts (share codes 30 and 31), closed-end funds (share codes 14 and 15), real estate investment trusts (share codes 18 and 48), and units (share codes 70 and 71), we end up with 65,457 observations. Then, for each permanent number, we take the earliest observation and have 458 firms remaining. Sorting by permanent company number, we find that 75 of these companies have two different permanent numbers, which means they have two classes of shares issued. When we delete the firms with two different permanent numbers from our sample, we end up with 383 unique firm observations. These are all the firms that issued dual class shares during 1925-1992.

The sample we create above includes all the companies that issued dual class shares some time before 1993. Thus, it is possible that some of them might have gone back to unitary or may have been delisted. We go through the SEC filings of these firms in order to check whether they still persist as dual class public companies as of the beginning of 1993. With this test we identify 177 public companies that have multiple classes of shares with different voting rights as of January 1993. We identify these firms as our "dual class firms". Among these dual class firms we classify the 44 companies that have reclassified their multiple classes of stock into a single class between January 1993 and April 2002 as "unified firms".

Next we identify the unified and dual class firms that engage in takeovers in the sample period. For this, we search Thomson Reuters' Security Data Corporation (SDC) Platinum Worldwide Mergers and Acquisitions database to identify the takeovers where the sample firms were listed as the acquirer in this database. The firms that engage in these takeovers form our final sample. We obtain our stock price and market return data from CRSP, firm-specific data from COMPUSTAT, and issue-specific data for our sample firms from the SDC Platinum database.

\subsection{Sample Characteristics}

Our sample period is 1993 to 2009. We have a total of 852 acquisitions in our sample. 211 of these acquisitions were made by firms who have unified their stock whereas the remaining 641acquisitions were made by firms that did not unify their stocks. Each firm in our sample had only one acquisition in each of the years in the sample period. Hence the number of acquisitions is equal to the number of firms in each year.

Table 1 shows the number of acquisitions in each year within the sample period. The highest number of acquisitions was in 1997 with 81 firms and the lowest number of acquisitions was in 2009 with 22 firms. There is a 
general decrease in the number of acquisitions during the sample period. Out of the 17 years in the sample period, there were a total of 540 acquisitions in the first 8 years as opposed to 312 acquisitions in the last 9 years. We observe a similar pattern for unified and non-unified sub-samples. $62 \%$ of the acquisitions made by unified firms were in the first 8 years, while $64 \%$ of the acquisitions by non-unified firms were in the same period. The highest numbers of acquisitions (27 and 63 firms respectively) ocurred in the first half of the sample period for both unified and non-unified firms while the lowest numbers of acquisitions ( 5 and 15 firms respectively) were completed in the second half.

Table 1

Annual Distribution of Sample Firms

\begin{tabular}{|c|c|c|c|}
\hline \multicolumn{4}{|c|}{$\begin{array}{l}\text { This table presents the annual distribution of acquisitions during the sample period. The sample consists of firms with unified and } \\
\text { dual class stocks that have acquired other firms between } 1993 \text { and } 2009 \text {. We obtain our sample of dual class and unified firms } \\
\text { from CRSP and acquisitions from the SDC database. }\end{array}$} \\
\hline Year & Unified & Dual class & Total \\
\hline 1993 & 19 & 45 & 64 \\
\hline 1994 & 16 & 48 & 64 \\
\hline 1995 & 17 & 50 & 67 \\
\hline 1996 & 11 & 42 & 53 \\
\hline 1997 & 27 & 54 & 81 \\
\hline 1998 & 19 & 57 & 76 \\
\hline 1999 & 14 & 63 & 77 \\
\hline 2000 & 8 & 50 & 58 \\
\hline 2001 & 11 & 31 & 42 \\
\hline 2002 & 10 & 27 & 37 \\
\hline 2003 & 8 & 31 & 39 \\
\hline 2004 & 11 & 23 & 34 \\
\hline 2005 & 10 & 31 & 41 \\
\hline 2006 & 5 & 33 & 38 \\
\hline 2007 & 6 & 25 & 31 \\
\hline 2008 & 13 & 15 & 28 \\
\hline 2009 & 6 & 16 & 22 \\
\hline Total & 211 & 641 & 852 \\
\hline
\end{tabular}

Table 2 shows the characteristics of the firms and acquisitions in the sample. In Panel A we present the mean and median values for the continuous variables while in Panel B we show the percentage values for each category of the discrete variables. In Panel A, total assets is defined as the total book value of assets. The average total assets in the sample is about $\$ 5$ billion while the median total assets is about $\$ 1.3$ billion. Both the mean and median total assets are higher for unified firms. Our second proxy for the size of the firm, the market value of equity, also shows that the unified firms are larger. The median market value of equity for a unified firm is \$ 2.4 billion, significantly higher than the $\$ 886$ million value for dual class firms. The market value of equity is defined as price multiplied by the number of common shares outstanding.

Our measure of the growth opportunities of the firm is the market-to-book ratio. We define market-to-book ratio as the price multiplied by the company's common shares outstanding, divided by common equity. The average market-to-book ratio for the firm is 1.86. Our results show that the average ratio is higher for unified firms indicating that unified firms have higher growth opportunities compared to dual class firms. In Panel A of Table 2, we measure leverage of the firm with the total debt ratio, defined as the sum of long-term debt and debt in current liabilities, divided by the book value of total assets. The mean debt ratio in the sample is $30.69 \%$ while the median is $25.38 \%$. Both the mean and median debt ratios are higher for dual class firms. The average of the total assets of target firms in the sample is $\$ 393.81$ million dollars and there is no significant difference in this variable between the unified and dual class firms. Coupled with the finding that unified firms are themselves larger firms, this finding indicates that these firms acquire smaller firms compared to their own size. The average transaction value, defined as the total dollar amount paid by the acquiring firm, is $\$ 393.81$ million. This value is significantly higher for dual class firms. On average, firms in the sample acquire $88.78 \%$ of the shares of target firms. This figure is $91.73 \%$ for unified firms, significantly higher than the $87.81 \%$ value for dual class firms. 
Table 2

Firm and Deal Characteristics

This table presents the characteristics of the firms and acquisition deals in the sample. The sample consists of firms with unified and dual class stocks that have acquired other firms between 1993 and 2009. We obtain our sample of dual class and unified firms from CRSP and acquisitions from the SDC database. Panel A shows the mean and median (in parentheses) values of the continuous variables. Total Assets is the total book value of assets. Market Value of Equity is the price multiplied by the number of common shares outstanding. Market-to-Book Ratio is the price multiplied by the company's common shares outstanding, divided by common equity. Total Debt Ratio is the sum of long-term debt and debt in current liabilities, divided by the book value of total assets. Target Total Assets is the total assets of the acquired firm. Transaction value is the dollar amount paid in the acquisition. Shares Acquired is the percentage of the shares of the target firm acquired. Panel B shows the percentage of the sample in each category of the discrete variables. Bid Type is the type of bid used in the transaction. Exchange is the stock exchange the company's common stock is listed. Purpose is the reason the acquiring firm states for the acquisition. Acquisition technique is the method used in the acquisition., deal-specific variables are obtained from the SDC database and firm-specific variables are obtained from Compustat. The numbers in "Difference" column show the differences of the variables for the unified firms and dual class firms. We use t-tests to test for the differences in means and median scores test to test for the differences in medians. $* * *, * *$, and $*$ denote significance at 1,5 and 10 percent levels respectively.

\begin{tabular}{|c|c|c|c|c|c|c|}
\hline \multicolumn{7}{|l|}{ Panel A } \\
\hline \multicolumn{2}{|c|}{ Variable } & All Firms & Unified Firms & \multicolumn{2}{|c|}{ Dual class Firms } & Difference \\
\hline \multirow{2}{*}{\multicolumn{2}{|c|}{ Total Assets }} & 5097.53 & \multirow{2}{*}{$\begin{array}{l}13264.00 \\
(2364.32)\end{array}$} & \multicolumn{2}{|c|}{3900.49} & $9363.51 * * *$ \\
\hline & & $(1296.26)$ & & & $.26)$ & $(1207.04)^{* *}$ \\
\hline \multirow{2}{*}{\multicolumn{2}{|c|}{ Market Value of Equity }} & 2920.16 & \multirow{2}{*}{$\begin{array}{c}3082.79 \\
(2555.73)\end{array}$} & \multicolumn{2}{|c|}{2896.24} & 186.55 \\
\hline & & $(919.46)$ & & \multicolumn{2}{|c|}{$(886.01)$} & $(1669.72)^{* *}$ \\
\hline \multirow{2}{*}{\multicolumn{2}{|c|}{ Market-to-Book Ratio }} & 1.86 & 3.29 & \multirow{2}{*}{\multicolumn{2}{|c|}{$\begin{array}{c}1.65 \\
(1.86)\end{array}$}} & $1.64 * *$ \\
\hline & & $(1.86)$ & $(1.86)$ & & & $(-0.08)$ \\
\hline \multirow{2}{*}{\multicolumn{2}{|c|}{ Total Debt Ratio (\%) }} & 30.69 & 20.01 & \multicolumn{2}{|c|}{32.26} & $-12.26 * * *$ \\
\hline & & $(25.38)$ & $(17.41)$ & \multicolumn{2}{|c|}{$(26.91)$} & $(-9.50)^{* *}$ \\
\hline \multirow{2}{*}{\multicolumn{2}{|c|}{ Target Total Assets }} & 1007.20 & 1544.64 & \multirow{2}{*}{\multicolumn{2}{|c|}{$\begin{array}{l}743.62 \\
(97.20)\end{array}$}} & 801.02 \\
\hline & & $(104.85)$ & $(144.50)$ & & & $(47.30)$ \\
\hline \multirow{2}{*}{\multicolumn{2}{|c|}{ Transaction Value }} & 393.81 & 173.59 & \multirow{2}{*}{\multicolumn{2}{|c|}{$\begin{array}{l}466.30 \\
(36.00)\end{array}$}} & $-292.71 * *$ \\
\hline & & $(35.96)$ & $(35.80)$ & & & $(-0.20)$ \\
\hline \multirow{2}{*}{\multicolumn{2}{|c|}{ Shares Acquired (\%) }} & 88.78 & 91.73 & \multirow{2}{*}{\multicolumn{2}{|c|}{$\begin{array}{c}87.81 \\
(100.00)\end{array}$}} & $3.92 * *$ \\
\hline & & $(100.00)$ & $(100.00)$ & & & $(0.00)$ \\
\hline \multicolumn{7}{|l|}{ Panel B } \\
\hline Variable & \multicolumn{2}{|c|}{ Categories } & All Firms & Jnified Firms & $\begin{array}{c}\text { Dual class } \\
\text { Firms }\end{array}$ & Difference \\
\hline \multirow{2}{*}{ Bid Type } & \multicolumn{2}{|c|}{ Tender Offer } & $96.37 \%$ & $98.58 \%$ & $95.64 \%$ & $2.94 \%$ \\
\hline & \multicolumn{2}{|c|}{ Other } & $3.63 \%$ & $1.42 \%$ & $4.36 \%$ & $-2.94 \%$ \\
\hline \multirow{3}{*}{ Exchange } & \multicolumn{2}{|l|}{ NYSE } & $64.25 \%$ & $68.89 \%$ & $63.58 \%$ & $5.31 \%$ \\
\hline & \multicolumn{2}{|c|}{ NASDAQ } & $29.33 \%$ & $31.11 \%$ & $29.07 \%$ & $2.04 \%$ \\
\hline & Strengt & Operations & $39.17 \%$ & $50.82 \%$ & $34.61 \%$ & $16.21 \%$ \\
\hline Purpose & Offer $\mathrm{N}$ & & $12.44 \%$ & $13.11 \%$ & $12.18 \%$ & $0.93 \%$ \\
\hline & Create & & $5.53 \%$ & $9.84 \%$ & $3.85 \%$ & $5.99 \%$ \\
\hline & Divesti & & $39.98 \%$ & $38.39 \%$ & $40.50 \%$ & $2.11 \%$ \\
\hline $\begin{array}{l}\text { Acquisition } \\
\text { Technigue }\end{array}$ & Open $\mathrm{N}$ & ase & $1.41 \%$ & $3.79 \%$ & $0.62 \%$ & $3.17 \%$ \\
\hline Technique & Stock s & & $10.32 \%$ & $19.43 \%$ & $7.32 \%$ & $12.11 \%$ \\
\hline
\end{tabular}

Panel B of Table 2 shows that $96.37 \%$ of the firms in the sample made a tender offer for the shares of the target firms. This percentage is 98.58 for unified firms and 95.64 for dual class firms. The majority of the firms in the whole sample and the unified and dual class sub-samples are traded on the New York Stock Exchange while about one third trade on NASDAQ. About half of the unified firms indicated that their purpose with the acquisition is to strengthen existing operations and expand presence in the primary market. This was the purpose for $34.61 \%$ of the dual class firms. $13.11 \%$ of the unified firms made the acquisition to offer new products while $12.18 \%$ of the dual class-firms had this purpose. $9.84 \%$ of unified firms wanted to create synergies with the acquisitions while 3.85 $\%$ of dual class firms had the same purpose. The predominant acquisition technique employed was divestiture. A stock swap was the second most popular acquisition technique for the whole sample and the two sub-samples while open market purchases was the third most popular method for all samples. 


\subsection{Stock Price Effects}

Table 3 shows the stock price effects of the acquisitions in our sample. In this table we test our hypothesis that the change in the market value of acquirer firms at the announcement of the takeover will be more favorable for unified firms compared to dual class firms. We calculate the abnormal returns using the market model. In this model we estimate beta using the CRSP value-weighted index over 240 days ending 11 days before day 0 , the acquisition announcement date.

Table 3

Announcement Returns

This table presents the cumulative abnormal returns of the acquisitions in the sample. The sample consists of firms with unified and dual class stocks that have acquired other firms between 1993 and 2009. We obtain our sample of dual class and unified firms from CRSP and acquisitions from the SDC database. Abnormal returns are calculated using the market model, beta is estimated using CRSP value-weighted index over 240 days ending 11 days before day 0, the acquisition announcement date. Stock returns are obtained from CRSP. Mean abnormal returns are in the first row in each cell and the median abnormal returns are in parentheses. We use t-test to test the significance of the means and sign rank test for the medians. The numbers in "Difference" column show the differences of the abnormal returns for the unified firms and dual class firms. We use t-tests to test for the differences in means and median scores test to test for the differences in medians. ***, **, and $*$ denote significance at 1 , 5 and 10 percent levels respectively.

\begin{tabular}{lcccc}
\hline Measure & All firms & Unified Firms & Dual class Firms & Difference \\
\hline CAR $(-5,+5)$ & 0.0040 & -0.0041 & 0.0054 & -0.0095 \\
& -0.0013 & $(-0.0043)$ & $(-0.0011)$ & $(-0.0032)$ \\
CAR $(-3,+3)$ & 0.0025 & 0.0029 & 0.0025 & 0.0004 \\
& $(0.0002)$ & $(-0.0025)$ & $(0.0005)$ & $(-0.0029)$ \\
CAR $(-1,+1)$ & $0.0065^{* *}$ & 0.0033 & $0.0070^{* *}$ & -0.0038 \\
& $\left(0.0031^{* *}\right)$ & $(0.0036)$ & $\left(0.0031^{* *}\right)$ & $(0.0006)$ \\
CAR $(-1,0)$ & $0.0037^{*}$ & 0.0054 & 0.0035 & 0.0019 \\
CAR $(0,+1)$ & $(-0.0007)$ & $(0.0047)$ & $(-0.0020)$ & $(0.0066)$ \\
& 0.0029 & 0.0053 & 0.0025 & 0.0028 \\
\end{tabular}

Consistent with Asquith (1983) and Eckbo (1983), we find that overall our sample firms obtain insignificant returns when they acquire other firms. For example, for the days -5 to +5 where day 0 is the announcement date of the acquisition, on average, firms obtain abnormal returns of $0.4 \%$, insignificant at the conventional significance levels. The announcement returns are significant and positive only for the $(-1,+1)$ period when firms obtain $0.65 \%$ return on average. For the unified sub-sample the returns are insignificant for all five announcement periods we study. For example, for the $(-5,+5)$ period, on average, unified firms obtain an insignificant $-0.41 \%$ return. Dual class firms obtain significantly positive returns in the $(-1,+1)$ periods. The average abnormal return during this period is $0.7 \%$ while the median abnormal return is $0.31 \%$, significant at the $5 \%$ level. Consistent with our hypothesis that unified firms have a more favorable change in their market value in a takeover, we find that for most of the announcement periods we study, unified firms obtain higher abnormal returns. However, our tests indicate that these differences are statistically insignificant. Hence, we do not find support for our hypothesis that unified firms obtain higher abnormal returns than dual class firms in takeovers.

In Table 4 we present the results of the multivariate OLS regressions run on the announcement returns. In these regressions the dependent variable is the two-day announcement returns for days $(0,+1)$. Announcement returns are defined the same way as in Table 3. In Table 4, we test whether unified and dual class firms have different announcement returns using the dummy variable "Type" which takes the value of one for unified firms and zero for dual class firms.

We use several control variables that we identified as possible factors that may influence the announcement returns in the hypothesis section of this paper. One of these variables is "Tender Offer" which takes the value of one for firms that used the tender offer method in the acquisition and zero for other types of offers. "Total Assets" is the total book value of total assets. "Payment" is a dummy variable that takes the value of one for cash offers and zero for other methods while "Public" takes the value of one when the target is a public firm and zero for private targets. "Purpose" is a dummy variable that takes the value of one for firms that expand their operations geographically 
and/or increase their market share as a result of the acquisition while "Same Industry" is a dummy variable that takes the value of one if the bidder and target share the same one digit SIC code and zero otherwise. "Tobin's Q" is the market value of the acquirer's equity as of the calendar year-end prior to the announcement plus the book value of debt and preferred stock from the most recent financial statement prior to the acquisition announcement divided by the sum of the book value of equity, debt, and preferred stock as of the same date.

Table 4

Announcement Return Regressions

This table presents the OLS regressions of the cumulative abnormal returns that the sample firms obtained when they announced their acquisitions. The sample consists of firms with unified and dual class stocks that have acquired other firms between 1993 and 2009. We obtain our sample of dual class and unified firms from CRSP and acquisitions from the SDC database. Abnormal returns are calculated using the market model, beta is estimated using CRSP value-weighted index over 240 days ending 11 days before day 0 , the acquisition announcement date. Stock returns are obtained from CRSP. The dependent variable is the two day announcement returns for days $(0,+1)$ where day zero is the acquisition announcement date.

Type is a dummy variable that takes the value of one for unified firms and zero for dual class firms. Tender Offer takes the value of one for firms that used the tender offer method in the acquisition and zero for other types of offers. Total Assets is the total book value of total assets. Payment is a dummy variable that takes the value of one for cash offers and zero for others methods while Public takes the value of one when the target is a public firms and zero for private targets. Purpose is a dummy variable takes the value of one for firms that expand their operations geographically and/or increase their market share as a result of the acquisition. Same Industry takes the value of one if the bidder and target share the same one digit SIC code and zero otherwise. Tobin's Q is the market value of the acquirer's equity as of the calendar year-end prior to the announcement plus the book value of debt and preferred stock from the most recent financial statement prior to the acquisition announcement divided by the sum of the book value of equity, debt, and preferred stock as of the same date. T-statistics are in parentheses. We obtain acquisitionspecific data from the SDC database and firm=specific data from COMPUSTAT. ***, **, and * denote significance at 1,5 and 10 percent levels respectively.

\begin{tabular}{|c|c|c|c|c|c|}
\hline Variable & Reg 1 & $\operatorname{Reg} 2$ & Reg 3 & $\operatorname{Reg} 4$ & $\operatorname{Reg} 5$ \\
\hline \multirow{2}{*}{ Intercept } & 0.0267 & 0.0208 & 0.0247 & 0.0250 & 0.0271 \\
\hline & $(2.57)$ & $(2.26)$ & $(2.64)$ & $(2.42)$ & $(2.61)$ \\
\hline \multirow{2}{*}{ Type } & 0.0090 & 0.0085 & 0.0087 & 0.0079 & 0.0076 \\
\hline & $(1.45)$ & (1.39) & $(1.43)$ & $(1.29)$ & $(1.25)$ \\
\hline \multirow{2}{*}{ Tender Offer } & 0.0122 & 0.0123 & 0.0119 & 0.0116 & 0.0060 \\
\hline & $(1.15)$ & (1.16) & $(1.12)$ & (1.09) & $(0.62)$ \\
\hline \multirow{2}{*}{ Total Assets } & $-0.0029 * *$ & $-0.0026 * *$ & $-0.0028 * *$ & $-0.0029 * *$ & $-0.0031 * * *$ \\
\hline & $(-2.49)$ & $(-2.27)$ & $(-2.46)$ & $(-2.48)$ & $(-2.71)$ \\
\hline \multirow{2}{*}{ Payment } & $0.0077 *$ & $0.0078 *$ & $0.0079 *$ & $0.0074 *$ & $0.0082 *$ \\
\hline & $(1.79)$ & $(1.82)$ & $(1.83)$ & $(1.71)$ & $(1.89)$ \\
\hline \multirow{2}{*}{ Public } & -0.0077 & -0.0075 & -0.0078 & -0.0073 & \\
\hline & $(-1.40)$ & $(-1.37)$ & $(-1.42)$ & $(-1.34)$ & \\
\hline \multirow{2}{*}{ Purpose } & -0.0093 & -0.0090 & -0.0091 & & -0.0090 \\
\hline & $(-1.57)$ & $(-1.50)$ & $(-1.53)$ & & $(-1.51)$ \\
\hline \multirow{2}{*}{ Same Industry } & -0.0020 & -0.0014 & & -0.0013 & -0.0023 \\
\hline & $(-0.44)$ & $(-0.31)$ & & $(-0.28)$ & $(-0.50)$ \\
\hline \multirow{2}{*}{ Tobin's Q } & -0.0014 & & -0.0014 & -0.0014 & -0.0014 \\
\hline & $(-0.96)$ & & $(-0.93)$ & $(-0.91)$ & $(-0.93)$ \\
\hline $\mathrm{N}$ & 348 & 350 & 348 & 348 & 348 \\
\hline $\mathrm{F}$ & $2.26 * *$ & $2.37 * *$ & $2.56 * *$ & $2.22 * *$ & $2.29 * *$ \\
\hline Adjusted $\mathrm{R}^{2}$ & 0.0281 & 0.0267 & 0.0304 & 0.0240 & 0.0254 \\
\hline
\end{tabular}

Consistent with our hypothesis that unified firms should obtain higher abnormal returns than dual class firms, we find that the coefficient of the "Type" variable is positive. However, this coefficient is insignificant at the conventional significance levels. Hence, in Table 4 we confirm our findings with the univariate analysis and fail to find strong support for our hypothesis that unified firms obtain higher announcement returns at takeovers compared to dual class firms. Table 4 also shows that the coefficient of total assets is significantly negative in all regressions and shows that larger unified and dual class firms obtain lower announcement returns. This finding is consistent with Moeller et al. (2004) and shows that larger firms obtain lower returns in acquisitions. In Table 4 the coefficient of the payment variable is positive and significant in all regressions. This finding shows that firms that pay for the acquisition in cash obtain higher announcement returns compared to firms that choose to use other payment methods. Our finding is consistent with Travlos (1987) and Fuller et al. (2002) who also show that in cash offers 
firms obtain higher returns compared to stock offers. The regression results also show that as we hypothesized the coefficient of the tender offer variable is positive while the coefficient for the public variable is negative. However, these coefficients are not significant at the conventional levels. The coefficients of the purpose, same industry, and Tobin's $Q$ variables are also insignificant.

Table 5

Announcement Return Regressions with Interactive Variables

This table presents the OLS regressions of the announcement returns of the sample firms with interactive terms as dependent variables. The sample consists of firms with unified and dual class stocks that have acquired other firms between 1993 and 2009. We obtain our sample of dual class and unified firms from CRSP and acquisitions from the SDC database. Abnormal returns are calculated using the market model, beta is estimated using CRSP value-weighted index over 240 days ending 11 days before day 0 , the acquisition announcement date. Stock returns are obtained from CRSP. The dependent variable is the two day announcement returns for days $(0,+1)$ where day zero is the acquisition announcement date. Type is a dummy variable that takes the value of one for unified firms and zero for dual class firms. Tender Offer takes the value of one for firms that used the tender offer method in the acquisition and zero for other types of offers. Total Assets is the total book value of total assets. Payment is a dummy variable that takes the value of one for cash offers and zero for others methods while Public takes the value of one when the target is a public firms and zero for private targets. Purpose is a dummy variable takes the value of one for firms that expand their operations geographically and/or increase their market share as a result of the acquisition. Same Industry takes the value of one if the bidder and target share the same one digit SIC code and zero otherwise. Tobin's Q is the market value of the acquirer's equity as of the calendar year-end prior to the announcement plus the book value of debt and preferred stock from the most recent financial statement prior to the acquisition announcement divided by the sum of the book value of equity, debt, and preferred stock as of the same date. The interactive terms are defined as each variable times the type dummy. T-statistics are in parentheses. We obtain acquisition-specific data from the SDC database and firm $=$ specific data from COMPUSTAT. ***, **, and * denote significance at 1,5 and 10 percent levels respectively.

\begin{tabular}{|c|c|c|c|c|c|}
\hline Variable & Reg 1 & $\operatorname{Reg} 2$ & Reg 3 & $\operatorname{Reg} 4$ & Reg 5 \\
\hline \multirow{2}{*}{ Intercept } & 0.0287 & 0.0213 & 0.0320 & 0.0261 & 0.0047 \\
\hline & $(2.71)$ & $(2.30)$ & $(3.07)$ & $(2.49)$ & $(0.85)$ \\
\hline \multirow{2}{*}{ Tender Offer } & -0.0039 & -0.0040 & 0.0009 & -0.0043 & -0.0015 \\
\hline & $(-0.34)$ & $(-0.34)$ & $(0.08)$ & $(-0.37)$ & $(-0.13)$ \\
\hline \multirow{2}{*}{ Tender Offer $*$ Type } & $0.0957 * * *$ & $0.0959 * * *$ & $0.0967 * * *$ & $0.0924 * * *$ & $0.0873 * * *$ \\
\hline & (3.38) & (3.41) & (3.63) & (3.28) & (3.22) \\
\hline Total Assets & $\begin{array}{c}-0.0033 * * * \\
(-2.72)\end{array}$ & $\begin{array}{c}-0.0029 * * \\
(-2.52)\end{array}$ & $\begin{array}{c}-0.0034 * * * \\
(-2.76)\end{array}$ & $\begin{array}{c}-0.0032 * * * \\
(-2.64)\end{array}$ & \\
\hline Total Assets * Type & $\begin{array}{c}0.0040^{*} \\
(1.83)\end{array}$ & $\begin{array}{c}0.0038^{*} \\
(2.22)\end{array}$ & $\begin{array}{c}0.0043 * * \\
(2.07)\end{array}$ & $\begin{array}{c}0.0034 * \\
(1.60)\end{array}$ & \\
\hline Payment & $\begin{array}{c}0.0073 \\
(1.59)\end{array}$ & $\begin{array}{c}0.0073 \\
(1.61)\end{array}$ & & $\begin{array}{c}0.0070 \\
(1.52)\end{array}$ & $\begin{array}{l}0.0071 \\
(1.53)\end{array}$ \\
\hline Payment $*$ Type & $\begin{array}{l}0.0007 \\
(0.06)\end{array}$ & $\begin{array}{c}0.0013 \\
(0.11)\end{array}$ & & $\begin{array}{l}0.0008 \\
(0.06)\end{array}$ & $\begin{array}{c}0.0063 \\
(0.54)\end{array}$ \\
\hline Public & $\begin{array}{l}-0.0003 \\
(-0.04)\end{array}$ & $\begin{array}{c}-0.0003 \\
(-0.04)\end{array}$ & $\begin{array}{c}-0.0007 \\
(-0.11)\end{array}$ & $\begin{array}{l}0.0002 \\
(0.03)\end{array}$ & $\begin{array}{c}-0.0029 \\
(-0.49)\end{array}$ \\
\hline Public * Type & $\begin{array}{c}-0.0318 * * \\
(-2.23)\end{array}$ & $\begin{array}{c}-0.0317 * * \\
(-2.23)\end{array}$ & $\begin{array}{c}-0.0334 * * \\
(-2.39)\end{array}$ & $\begin{array}{c}-0.0340 * * \\
(-2.39)\end{array}$ & $\begin{array}{c}-0.0271^{*} \\
(-1.91)\end{array}$ \\
\hline Purpose & $\begin{array}{c}-0.0086 \\
(-1.32)\end{array}$ & $\begin{array}{c}-0.0082 \\
(-1.26)\end{array}$ & $\begin{array}{c}-0.0078 \\
(-1.20)\end{array}$ & & $\begin{array}{c}-0.0095 \\
(-1.44)\end{array}$ \\
\hline Purpose * Type & $\begin{array}{c}-0.0079 \\
(-0.52)\end{array}$ & $\begin{array}{c}-0.0070 \\
(-0.47)\end{array}$ & $\begin{array}{c}-0.0090 \\
(-0.60)\end{array}$ & & $\begin{array}{c}0.0006 \\
(0.04)\end{array}$ \\
\hline Same Industry & $\begin{array}{l}0.0005 \\
(0.11)\end{array}$ & $\begin{array}{c}0.0008 \\
(0.18)\end{array}$ & $\begin{array}{c}-0.0001 \\
(-0.03)\end{array}$ & $\begin{array}{l}0.0011 \\
(0.24)\end{array}$ & $\begin{array}{l}0.0011 \\
(0.23)\end{array}$ \\
\hline Same Industry * Type & $\begin{array}{c}-0.0219 \\
(-1.48)\end{array}$ & $\begin{array}{c}-0.0189 \\
(-1.34)\end{array}$ & $\begin{array}{c}-0.0212 \\
(-1.45)\end{array}$ & $\begin{array}{c}-0.0173 \\
(-1.21)\end{array}$ & $\begin{array}{c}-0.0052 \\
(-0.47)\end{array}$ \\
\hline Tobin's Q & $\begin{array}{l}-0.0020 \\
(-1.27)\end{array}$ & & $\begin{array}{l}-0.0021 \\
(-1.32)\end{array}$ & $\begin{array}{c}-0.0019 \\
(-1.18)\end{array}$ & $\begin{array}{c}-0.0017 \\
(-1.07)\end{array}$ \\
\hline Tobin’s Q * Type & $\begin{array}{l}0.0007 \\
(0.18)\end{array}$ & & $\begin{array}{c}0.0004 \\
(0.11)\end{array}$ & $\begin{array}{c}0.0006 \\
(0.17)\end{array}$ & $\begin{array}{l}0.0047 \\
(1.57)\end{array}$ \\
\hline $\mathrm{N}$ & 348 & 350 & 348 & 348 & 348 \\
\hline $\mathrm{F}$ & $2.54 * * *$ & $2.78 * * *$ & $2.71 * * *$ & $2.69 * * *$ & $2.24 * * *$ \\
\hline Adjusted $\mathrm{R}^{2}$ & 0.0586 & 0.0578 & 0.0558 & 0.0553 & 0.0410 \\
\hline
\end{tabular}




\subsection{Factors Affecting Announcement Returns}

In Table 5, we test our hypothesis that the factors that influence the takeover announcement returns should have different effects for unified and dual class firms. The factors we study in this table are the variables we used as control variables in Table 4. In the regressions in Table 5 we use interactive terms with the "Type" variable as well as the variables themselves to measure the differential influences of these variables. For example, in order to measure the differential influence of the size of the firm we use:

$\mathrm{a} *($ Total Assets $)+\mathrm{b} *[($ Total Assets $) *($ Type $)]$

In the terms above, $\mathrm{a}$ and $\mathrm{b}$ are the regression coefficients while the "Type" variable is a dummy variable that takes the value of one for unified firms and zero for dual class firms. Hence, the coefficient of the total assets variable is the sum of the two coefficients $(a+b)$ for unified firms and only the coefficient for total assets (a) for dual class firms. Therefore, the sign and significance of the coefficient of the interactive term shows the differential influence of the size of the firm on the announcement returns of unified firms compared to that of dual class firms. As in Table 4, the dependent variable in these regressions is the two-day announcement returns for days $(0,+1)$.

The results in Table 5 show that the coefficient of the tender offer variable is negative and insignificant showing that dual class firms do not obtain higher announcement returns when they engage in tender offers. The interactive term [(Tender Offer) * (Type)], on the other hand, is positive and significant indicating that the influence of the tender offer variable is more positive for unified firms. Thus, unified firms that engage in tender offers are able to obtain better announcement returns than their dual class counterparts. Our results also show that the coefficient of Total Assets is negative. This finding indicates that large dual class firms obtain lower announcement returns. The coefficient of the interactive term [(Total Assets) * (Type)] is positive suggesting that the influence of size is more positive for unified firms. Thus, unified firms are able to obtain higher abnormal returns than large dual class firms. The variable "Public" has an insignificant coefficient while the interactive term [(Public) * (Type)] is significantly negative. This result shows that while the public variable does not have a significant influence on the announcement returns of dual class firms, the influence is more negative for unified firms. Hence, unified firms that acquire public firms obtain lower announcement returns compared to the announcement returns of their dual class counterparts. Other variables do not appear to have significant influences on the announcement returns.

The results in Table 5 provide support for our argument that the factors that the literature suggests have different influences for the announcement returns of unified and dual class firms. The unique features of unified and dual class firms lead these firms to obtain significantly different announcement returns even when they have similar deal-specific or firm-specific variables.

\section{CONCLUSION}

In this paper, we study the stock price effects of takeovers done by unified and dual class firms. We hypothesize that the announcement returns of unified firms will be higher than the announcement returns for dual class firms since the acquisition is generally less costly for unified firms and these firms do not experience moral hazard problems as much as dual class firms. We also identify several variables that the literature suggests should affect the announcement returns of our sample firms. We hypothesize that these variables will affect the announcement returns of unified firms and dual class firms differently.

Our sample consists of 211 acquisitions done by unified firms and 641 acquisitions done by dual class firms. Our univariate analysis results show that although unified firms obtain higher average and median abnormal returns than those obtained by dual class firms in most of the announcement periods we study, the differences in the announcement returns are not statistically significant. We also perform multivariate OLS regressions that test the influence of the unification dummy variable on the takeover announcement returns, while controlling for other factors that may affect the announcement returns. Consistent with our hypothesis we find that the coefficient of the unification dummy is positive but insignificant. This finding confirms the results of our univariate analysis. We also find that several factors that influence the announcement returns in takeovers have different influences for unified firms and dual class firms. Specifically in tender offers and when the acquirer is large, unified firms are able to 
obtain higher abnormal returns compared to dual class firms while they obtain lower returns when the target firm is a public company.

There have been numerous studies that study the factors that influence the announcement returns of takeovers. However, these studies failed to incorporate information on share classes into their analysis. This study shows the importance of incorporating share class structure into the analysis of corporate events in future studies.

\section{AUTHOR INFORMATION}

Dr. Onur Arugaslan's primary teaching interests are in the areas of personal financial planning, corporate finance, financial strategy, and international finance. His research includes the separation of cash flow rights and voting rights, the endogeneity of liquidity, the risk-adjusted performance of American Depository Receipts and the market reaction to the acquisitions by unified dual class firms. Arugaslan has published articles in the Journal of Finance and the Journal of Corporate Finance. His research received Best Paper Award at the 2006 Association for Global Business Conference and a Highly Commended Paper Award at Emerald Literati Network Awards for Excellence 2008. E-mail: onur.arugaslan@wmich.edu

Dr. Jim DeMello's primary teaching interests are in the areas of corporate finance, investments, and security analysis. DeMello is the author of "Cases in Finance." He has presented seminars on "Finance for Non- Financial Managers" as well as research papers at various regional and national conferences. His primary research interests include mergers and acquisitions, capital market efficiency, and stock selection strategies. His publications have appeared in the Financial Analysts Journal, Journal of Portfolio Management, Journal of Fixed Income and Financial Practice and Education. E-mail: james.demello@wmich.edu

Dr. Yaman has conducted research in a variety of topics including debt and equity issues, earnings warnings, and corporate takeovers. Her research has been published in the Journal of Banking and Finance, Financial Management, Financial Review, and the Quarterly Review of Economics and Finance. She has also presented her research at several national and international conferences. She teaches corporate finance, computer applications in finance, and investments courses. Dr. Yaman is a CFA charterholder and has worked at the Eximbank of Turkey. E-mail: devrim.yaman@wmich.edu. Corresponding author.

\section{REFERENCES}

1. $\quad$ Arugaslan, O. 2007. "Why Are Dual Class Shares Unified." Business Quest 12: pp 1-25.

2. $\quad$ Asquith, P. 1983. "Merger Bids, Uncertainty, and Stockholder Returns." Journal of Financial Economics 11: pp 51-83.

3. Bigelli, M. and S. Mengoli. 2004. "Sub-Optimal Acquisition Decisions Under a Majority Shareholder System." Journal of Management and Governance 8: pp 373-405.

4. Chang, S. 1998. "Takeovers of Privately Held Targets, Methods of Payment, and Bidder Returns." Journal of Finance 53: pp 773-784.

5. $\quad$ Copeland, J.F. and T.E. Weston. 1992. Managerial Finance. Dryden Press.

6. $\quad$ Draper, P. and K. Paudyal. 2006. “Acquisitions: Private versus Public.” European Financial Management 12: pp 57-80.

7. $\quad$ Eckbo, B. E. 1983. "Horizontal Mergers, Collusion, and Stockholder Wealth." Journal of Financial Economics 11: pp 241-273.

8. Faccio, M., J.J. McConnell, and D. Stolin. 2006. "Returns to Acquirers of Listed and Unlisted Targets." Journal of Financial and Quantitative Analysis 41: pp 197-220.

9. $\quad$ Fischel, D.R. 1987. "Organized Exchanges and the Regulation of Dual Class Common Stock." University of Chicago Law Review 54: pp 119-152.

10. Fuller, K., J. Netter, and M. Stegemoller. 2002. "What Do Returns to Acquiring Firms Tell Us? Evidence from Firms That Make Many Acquisitions." Journal of Finance 57: pp 1763-1793.

11. Holmen, M. and E. Nivorozkin. 2005. "The Impact of Dual Class Shares on Takeover Risk and the Market for Corporate Control.” Working Paper. Uppsala University. 
12. Lang, L.H.P., R. Stulz, and R.A. Walkling. 1989. "Managerial Performance, Tobin's Q, and the Gains from Successful Tender Offers." Journal of Financial Economics 24: pp 137-154.

13. Lang, L.H.P., R. Stulz, and R.A. Walkling.1991. "A Test of the Free Cash Flow Hypothesis: The Case of Bidder Returns.” Journal of Financial Economics 29: pp 315-336.

14. Loderer, C. and K. Martin. 1990. "Corporate Acquisitions by Listed Firms: The Experience of a Comprehensive Sample.” Financial Management 19: pp 17-33.

15. Maquieira, C.P., W.L. Megginson, and L. Nail. 1995. "Security Market Assessments of Focus-Increasing Mergers. Working Paper. University of Georgia.

16. McCabe, G.M. and K.C. Yook. 1997. "Jensen, Myers-Majluf, Free Cash Flow and the Returns to Bidders." Quarterly Review of Economics and Finance 37: pp 697-707.

17. Moeller, S.B., F.P. Schlingemann, and R. Stulz. 2004. "Firm Size and the Gains from Acquisitions." Journal of Financial Economics 73: pp 201-228.

18. Morck, R., A. Shleifer, and R.W. Vishny. 1990. "Management Ownership and Market Valuation" An Empirical Analysis." Journal of Financial Economics 45: pp 31-48.

19. Pajuste A. 2005. "Determinants and Consequences of the Unification of Dual-Class Shares." Working Paper. European Central Bank.

20. Servaes, H. 1991. “Tobin's Q and the Gains from Takeovers.” Journal of Finance 46: pp 409-419.

21. Schwert, W.G. 2000. "Hostility in Takeovers: In the Eye of Beholders?” Journal of Finance 55: pp 25992640.

22. Travlos, N.G. 1987. “Corporate Takeover Bids, Method of Payment, and Bidding Firms' Stock Returns. Journal of Finance 42: pp 943-963.

23. Walker, M.M. 2000. "Corporate Takeovers, Strategic Objectives, and Acquiring-Firm Shareholder Wealth.” Financial Management 29: pp 53-66. 